\title{
THE CHARACTER EDUCATION IN ISLAMIC EDUCATION VIEWPOINT
}

\section{Djaswidi Al Hamdani}

Institute of Islamic Studies Darussalam (IAID), Ciamis, West Java-Indonesia Jl. KH. Ahmad Fadlil I Darussalam Kotak Pos No. 02 Ciamis

Email:dr.djaswidi@yahoo.com

\begin{abstract}
This paper intends to study the concept of character and moral education according to the terminology, approaches, and methods of learning from the point of view of Islamic education. The approach used in this paper is a discussion of the linguistic (al-lughah). The results showed that the conceptual basis of character education in the curriculum in Indonesia too much because it has a number of terminological problems. The concept of morals, values, and characters have a special meaning that may be different from one another. As a result, the concept of the character presented in the curriculum subject is far from the actual context of the moral and less with actually happening in the community. Character education is also too much use of the approach and methods indoctrinasi than critical, reflective and empirical and is not integrated with the system and school culture.
\end{abstract}

Keywords: Character, at-Ta'dīb, al-Akhläq, Islamic Education

\section{ABSTRAK}

Tulisan ini bermaksud mengkaji konsep karakter dan pendidikan moral menurut terminologi, pendekatan, dan metode pembelajaran dari sudut pandang pendidikan Islam. Pendekatan yang digunakan dalam penulisan ini adalah diskusi tentang linguistik (al-lughab). Hasil penelitian menunjukkan bahwa secara konseptual pendidikan karakter dalam kurikulum pendidikan di Indonesia terlalu berlebihan karena memiliki sejumlah masalah terminologis. Konsep moral, nilai, dan karakter memiliki makna khusus yang boleh jadi berbeda antara satu dengan yang lain. Akibatnya, konsep karakter yang disajikan dalam kurikulum mata pelajaran jauh dari konteks moral dan kurang aktual dengan sebenarnya terjadi di masyarakat. Pendidikan karakter juga terlalu banyak menggunakan pendekatan dan metode indoctrinasi daripada kritis, reflektif dan empiris serta tidak terintegrasi dengan sistem dan budaya sekolah.

Kata Kunci: Karakter, at-Ta'dīb, al-Akblāq, Pendidikan Islam

\section{INTRODUCTION}

The issue of the importance of character education has lively been discussed again at the same time with the increase of Indonesian's concern against intolerant, violence, terror, corruption, and other destructive behaviors and attitudes. Destructive behaviors, especially terror and corruption, which lately tend to increase in the society, has alerted the nation 
regarding the importance of character education, which actually had been a core curriculum in the New Order government.

During the New Order, Indonesian national character development is a main priority of national education. New Order government provided a significant portion for the student character development, especially through several lessons such as of Pancasila Moral Education (PMP), Pancasila and Citizenship Education (CIVICS). Unfortunately, the nature of the ideological character education at that time was very dominant, so that the character substance was developed much more oriented to develop Indonesian human-abiding and obedient to the leader, such as to work together, to maintain stability, and to 'human development'. Those character values were deliberately highlighted because only those who have such characters can become authorities who can maintain the status quo as well as support the success of development programs. On the other hand, the character values such as critical, honest, truth and openness side, and courage to defend the oppressed, have almost no place in the educational curriculum, because the character values not only can threaten national stability required for development but also they can undermine the authority of government power.

Based on the surface, the pattern of ideological character education with an emphasis on indoctrinal approaches seems to be successful. Evidently, for example, the tolerance between different groups of people can be maintained, violences against religion, ethnicity and race almost never occured, there is as if the corruption does not exist because there are almost no criminals processed through the judicial institution properly. But when it is examined deeper, the real conditions that made it look as if there were no irregularities character at that time was not due to the success patterns of character education in formal educational institutions, but it was caused by the repressive power of the authority.

At the same time, when Indonesia faced with a serious moral problem such as this, the academic world is again busy discussing urgency of implementing character education in educational institutions. Education experts and practitioners discuss the concept of the appropriate character education, which can reduce behaviors and cultures intolerance, violence, terror, and corruption. The phrase 'the appropriate concept of character education' needs to be emphasized, because as long as Indonesia has been implemented and repeatedly changed from one name to another name, but the results are considered to be not in accordance with the expected goals.

This article tries to explore the study of character education concepts with emphasis on problems of terminology, methods, and approaches. Emphasis on problems of terminology are intended to analyze a number of 
'terms' are applied in formal educational institutions in the country. Meanwhile, the problems of the approach and methods are directed to analyze a number of approaches and methods of character or akhlak education.

\section{DISCUSSION}

Efforts to develop the character of students in formal educational institutions in the country actually has been done for quite long time. Even in colonial times too, it has recognized the so-called moral education contains customary values and informal social institutions. In the early days of independence, the character development is done through a formal educational institution subjects, i.e., religious and moral education. By retaining the religious and moral education, in the 50 's, it began to be felt on the importance of the development of responsible citizens. This was the starting point for the emergence of civic education subjects in 1957. Citizenship education in 1961 was replaced by the subject of Civics, which in 1968 was changed again to the State Citizenship Education subjects.

In the $70 \mathrm{~s}$, the development of human character is more geared to form Indonesian human in accordance to the values of Pancasila. Then in 1975 appeared Pancasila Moral Education (PMP) oriented on inclucation values with the content Pancasila and the 1945 Constitution. Curriculum 1975 PMP was then refined back through 1984 PMP curriculum with maintaining its inculcation values but it contains Guidelines Understanding, appreciation, and practice of Pancasila (P4). Along with the enactment of Act s. 2. 1989 on National Education System, in 1994 there was a change of Pancasila Moral Education (PMP) to Pancasila and Citizenship Education (CIVICS), which still essentially contained curriculum with value inculcation and dissemination of knowledge domination. With the enactment of Act s. 20. 2003 on National Education System, then in 2004, there was a change on the terms of Pancasila and Citizenship Education (CIVICS) into Citizenship Education (PKN) which is directed at the development of civic virtue and civic culture.

In addition to Civics subject, there are a number of other subjects which also have the same goal, namely the subject of religious education in all schools and specific subject to the moral creed of madrasa education. In religious education curriculum for public schools, there are a special charge of moral education. Similar charge is contained in the creed of moral subjects in the madrasa education institutions. Thus, there are at least three subjects at formal education institutions in Indonesia (Civic Education, Religious Education, Aqidah Akbläq) in which their orientations, visions, and goals are more or less the same, i.e., to develop students' character, morality, responsibility as citizen. 
Logically, with a stack of moral or character education material and moral education, Indonesian people should have a steady, noble, superior morality, strong integrity, creative and innovative characters. But in fact, the Indonesian people are still faced with a serious moral problem, even from day to day the problem tends to decrease more and more serious. Evidently, corruption is rampant, real, and entrenched. Corruption is found almost everywhere and in almost all parts of life. Eradication efforts through a number of agencies, commissions, and task forces do not give maximum results yet, otherwise it has failed. The nation is also faced with the problem of intolerance, radicalism, and terrorism.

Many morality problems faced by the nation indicate that the character education that is packaged in a number of names has been ineffective. There is no scientific evidence that shows that the more children receive educational material character, the better their character. Although learners acquire character-education curriculum, for example through Citizenship Education, Religious Education, Morals and dogma, but the morality problem is not reduced. If now the Ministry of Education plans to introduce character education, then the question will be on how its impact and effectiveness are. Why? Because no matter how educational institutions in this country recognize some terms of character building but the substance and the material are quite similar.

It shows that terminological character education still needs to be discussed. There are a number of terms that need to be discussed, namely terms of character, values, morals, ethics, and morals. The term 'character' has long been concerned with the study of philosophy, theology, psychology, history, and sociology. In the most general sense, this term refers to the number of elements of personality 'expected' of a person. The elements of this character according to the American Institute for Character Education (AICE) include: courage, faith, generosity, kindness, helpfulness, honesty, honor, justice, tolerance, freedom of choice, freedom of speech, good citizens, the right to be an individual, and the right to equal opportunities; Meanwhile Wynne (1988, pp. 424-426 \& 1982) mentions that there are six elements of character, namely: "the wisdom (tack), honesty, adherence to a recognized authority (obedience to legitimate authority), persistence (Perseverance), humor (good bumor), and loyalty.

In Islamic terminology, akbläq is commonly interpreted as a moral character, behavior, character, or knowledge related to behavior, human behavior which is good or bad. Al-Mawdudi defines akbläq as a moral human behavior that exists since the birth of a person, which then becomes the norm to be accepted by society both good or bad morals. Akhlaq (moral) is good behavior that has become the custom person or group of persons. 
If character refers to the number of personality elements, so is the character. But the two differ in 1) the word 'character' in itself a positive connotation, as shown in the above definition AICE, while the word 'morality' (akbläq) means 'good morals' (al-akbläq al-mabmüdab) or 'bad character' (al-akbläq al-madrmumah) as the sense of morality according to AlMawdudi and Teuku Iskandar is; and 2) the concept of morals originated, developed, and laden with religious terms-terms, while the concept of rationality and character comes from human experience, particularly the West.

And the word 'moral' is derived from the Latin mos (plural: mores) means the habit, custom. mos word (mores) in Latin is synonymous with the Greek word ethos. Therefore, according to Daud, said ethics can't be separated from moral words. Because in his opinion, moral behavior is determined by ethics. Dictionary of Education defines morality as a term used to delimit those characters, traits, intentions, or acts roommates Judgments can appropriately be designated as right, wrong, good, bad. (a term used to define the boundaries of nature, temperament, desire, opinions or actions which can reasonably be said right, wrong, good, bad). Meanwhile, The Advanced leaner's Dictionary of Current English gives moral sense as: a) concerning principles of right and wrong; b) good and virtuous; c) Able to understand the difference between right and wrong; d) teaching or illustrating good behavior. Another term is also known value. According to Vijay Sathe, value is "Assumption basic ideals about what are desirable or worth striving for" or the basic assumptions about what is desirable or very ideal that is worth fighting for.

The concept of character, morals, values, morals, and ethics that actually have similar objectives in which in terminology, it is interpreted differently by some experts. These differences have implications for the emergence of a variety of educational concept which aims to educate and develop the character and morality of learners, ranging from moral education, religious education, moral education (moral education), moral education (ta'dīb al-akbläq), educational value (value education), until the character education (character education).

Terminology of moral education in the last two decades are commonly used to describe an investigations of ethical issues in the school environment. The learning of ethic values in moral education are more likely to convey moral values of right and wrong. Meanwhile the implementation of the moral values in personal lives, families, and communities receive less attention. As a result, moral education is more emphasis on its normative and it touches less actions and behaviors of learners. Moral education itself is the oldest terms of education aimed at teaching good values in human life. 
Meanwhile, the moral education as Ibn Miskawayh formulation is an attempt towards realization of an inner attitude which encourages spontaneously to bear good or bad deeds of a person. In this moral education, the criteria for judging right and wrong actions refer to Al-qur'an and the Sunna of the Prophet. If someone said that moral education is part of moral education in the educational discourse of Islam, in fact it is less precise view, since the ultimate goal of moral education is the formation of a positive character in the behavior of students. No other positive character is the embodiment of the noble qualities of God in human life. However, in the praxis of education, moral education still tends to the teaching of right and wrong as well as moral education.

Character education began bustling discussed since the 1990s, interpreted as a plus character education, which involves aspects of knowledge (cognitive), feeling, and action. However, character education has a broad scope and not easily discussed. When defining character education, Ryan and Bohlin (1999) says "it is about developing good habits and virtuesdispositions roommates leads students to responsible and mature adulthood." Character education must contain at least three basic elements, namely to know the goodness (knowing the good), loving kindness (loving the good), and do good (doing the good).

In Indonesia, there are many variety of educational concept that later becomes a separate subject. Learners in public schools obtain the subject Religious Education, Education citizenship and soon the Character Education. School learners in acquiring the three subjects plus subject Aqidab Akbläq. As a result, there are many charges redundancy character education. Most charge of character education on the subjects of Citizenship Education, for example, also present in subjects religion or creed Moral Education.

The second problematic with regard to the education and development of human character Indonesia is the approach and methods of education. The serious problem is believed to be approach and methods. It can even be said that the failure of Indonesia in developing its human characters is because the approach and methods of educational values, morals, or characters inappropriately. Problematic approach to character education is associated with at least two important questions: whether character education should be in the form of a separate subject or integrated into the school system/madrasah? In the context of Indonesia's multicultural society, what kind of the most appropriate approach in teaching character education is?

With regard to the first question, there are at least three views, namely character education is integrated into the entire curriculum, character education be part of other subjects, and character education as a separate subject. However, most experts recommend that character education is 
integrated into the school system, or put the whole school curriculum (infused throughout the curriculum). Rusnak (1992) suggested that character education is integrated into all subjects and in all daily activities of the school. Furthermore, Timothy G. Rusnak, et al suggest: "Ideally, the integration of character education into subject areas across the curriculum should be-adopted as a schoolvide policy if it is to be successful'. In this way, learning materials related to moral values on each subject can be developed, made explicit, and contextualized into everyday life. Thus, learning the values of the characters is not only on the cognitive, but it rather touches on internalization, experience, and practice in real life everyday learners.

As comparison, the results of a survey conducted by the IEA Civic Education to 133 principals in the UK concluded that $70 \%$ of respondents strongly disagreed civic education be used as a separate subject; $60 \%$ agreed if civic education subjects were integrated into the social sciences and humanities; and 50\% agreed when integrated into all subjects. Results of another study conducted Torney-Purta (2001) mentioned that teachers in most countries choose to integrate citizenship education in a particular subject or subjects on all. But the tendency in Asia, particularly in Hong Kong, Korea, and Singapore, it shows just the opposite, where the respondents in the three countries are more likely to choose citizenship education as a separate subject, among other reasons because of the teachers in the schools often fail to integrate issues moral issues into the learning activities. For them, the integrated curriculum is not very practical.

What happens in these three countries is not really different in Indonesia. Although a number of educational practitioners in the country suggests that character education is integrated into all subjects and become an integral part system school/madrasa, but in fact, character education remains a separate subject through Civic Education, Religious Education, Moral creed, or "Character Education" . Teachers who teach other subjects feel irresponsibility for character development of students.

Looking at the condition of the education curriculum in schools in the country, the option to integrate character education into all subjects and become an integral part system school/madrasah is the most realistic. Why? Because; 1) integrative curriculum can provide flexible options when it comes to contact with certain moral issues; 2) subjects and curriculum of schools that have been very much will be multiplied by adding a separate subject; and 3) the moral or character values are to be internalized and it is not to be taught as a science. Honesty, responsibility, caring, creativity, strength of mind, independence, attention, loyalty, kindness, perseverance, fairness, selfdiscipline, respect for the law, and the values of other characters not to be 
taught to students as knowledge, but to be internalized so that it becomes part of the learner's behavior in everyday life.

Another issue with regard to character education is the approach and method of learning in the classroom. During the education and character development of the students in the subjects of Civics, Religious Education, Morals and dogma, they are dominated by cultivation approaches (inculcation approach) with the main learning methods are: lecture, study textbooks, and indoctrination. Innovation and creativity to apply an alternative teaching methods and approaches are underdeveloped. In fact, the option to use the approach and methods of character education is quite varied.

Character education in the academic level is also known as educational value at the level of praxis can be implemented using a number of approaches. By tracing the value of education literature, there are at least five approaches commonly used character education in the decade of the 90s, namely the development of a rational approach, consideration approach, values clarification approach, the approach of cognitive moral development, and social behavioral approaches. Superka (1976) said; There are five approaches in charater education, namely 1) inculcation approach, 2) cognitive moral development approach, 3) values analysis approach, 4) values clarification approach, and 5) action learning approach. The simpler classification approach was made by Elias who divides it into three approaches, namely the cognitive, affective, and behavioral approaches. The classification is according to Rest (1994, pp. 36-60) based on three elements of morality that used to be the foundation of the study of psychology, namely: behavioral, cognitive, and affective.

First, the value inculcation approach is an approach that aims for learners to receive certain moral values and change their moral values as it is expected. The approach is supported by a number of learning methods among other ideals, positive and negative reinforcement, simulation, role play, lecture, is the traditional approach indoctrination, which in many Western literatures have been criticized for this approach since it is considered to be indoctrinate and not in accordance with the development of democracy. In addition to such criticism, this approach is also considered ignoring the rights of students to freely choose their own value. But some educators in the West still believe in this approach to named value and virtue to the younger generation, especially religious values and cultural values.

In Indonesia, the value inculcation approach still dominates the process of learning the subject Religious Education in a variety of education, including on subjects Aqidah Akhläq as one of the subjects are loaded with the values of the characters in the madrasa. This is because moral values or the character of Religious Education subject (schools) and Aqidah Akhläq 
(madrasa) extracted from truly sources in holy book as an absolute truth. Moral values or character contained in the holy book is undoubtedly true, so that students do not need to do the reasoning, criticism, let alone deny. That needs to be done by the teacher is implanting to all learners. Perhaps the stakeholders must concern that not all moral values in this approach contain doctrinal faith-based which cannot be reached by human reason critically. That the elements of character, morality, scripture-based character can also be understood rationally and critically analyzed, so that the learning method should not only use the lecture method, indoctrination, and methods of reinforcement.

Secondly, an approach that emphasizes on cognitive development and cognitive development. Through this approach, students are expected to be able to think critically, both on moral issues and in terms of making moral decisions. The approach was first introduced by Dewey and developed by Piaget and Kohlberg aiming to assist learners in making a moral reasoning which is more complex based on a higher value, as well as encouraging students to discuss the reasons when choosing the value and its position within a moral issue.

Based on this approach, moral development is considered as developmental level of thinking in making moral reasoning of a lower level towards a higher level. Dewey divides the child's moral development into three stages, namely: 1) premoral or preconventional phase. At this stage of a person's behavior is driven by the insistence biological or social nature; 2) a conventional stage, the stage at which a person begins to accept the value with little critical reflection of group standards; and 3) autonomous stage. At this stage a person acts or behaves in accordance with the reasoning and judgment itself, does not fully accept group criteria. Meanwhile Dewey's thoughy about moral development is very theoretical, Piaget describes the level of moral development of children based on observations and interviews in a game. From the results of interviews with the children when they play and the answer to the question why they stick to the rules, Piaget came to the conclusion that the development of cognitive abilities in children affect moral reasoning.

Approach to cognitive development is recognized as an approach that is relatively easy to be implemented in the educational process at school, because this approach gives emphasis on developmental aspects of thinking skills. This approach is also shown to improve classroom dynamics. However, this approach also contains a weakness, among other highly value personal freedom, less concerned with the criteria of an act wrong, and prefer the reason stated or moral considerations. Kohlberg's theory of development is also often criticized for its gender bias and more emphasis on 
the content process. In fact, according to Lickona (1992 \& 2007), with emphasis only on moral education purposively and ignore the contents, it will not achieve fully what to expect.

Third, value analysis approach which aims to equip learners to have the ability to apply logical thinking and scientific inquiry in dealing with the problems of moral values. This approach emphasizes on the development of students' ability to think logically by means of analyzing the problems associated with moral values. In contrast to the cognitive developmental approach which emphasizes on indvidual moral dilemmas, this approach is more emphasis on the discussion of issues that includes social values.

Moral or character education according to this approach is aimed at achieving two objectives, namely: 1) help learners to use the ability with logical thinking and scientific inquiry in analyzing the problems of moral values; and 2) help learners to use rational and analytical thought processes, the concept of linking and formulate their values. To achieve that goal, the learning method which is considered to be appropriate is to learn individually or group about social moral problem, literature searches, field studies, and class discussions.

Fourth, values clarification approach is the approach to character education that aims to; 1) help learners to recognize and identify their own values and the values of others; 2) assist learners in order to have the ability to communicate openly and honestly with others; and 3) help students to have the ability to use together rational thinking skills and emotional awareness to understand the feelings, values, and behavior patterns of their own. By using the method of learning dialogue, writing, discussion in large groups or small, this approach emphasizes on the effort to build and understand their own feelings and actions in increasing their awareness about their own moral values.

Fifth, learning approach is an approach that aims to 1) provide opportunities for learners to perform moral deeds, both individually and in groups, based on the moral values of their own; and 2) encourage learners to understand themselves as individual beings and social beings in the context of people who do not have complete freedom. Doing this learning approach, it can be applied to the learning methods used in the values analysis and values clarification approaches.

Indeed, in addition to the five that approach, there are other approaches that are not discussed in this paper. For example, a holistic approach, reflective moral inquiry, moral awareness, commitment approach, the union approach, and others. Choice of which approach is appropriate relies on the source of moral values/character, learners, environment, and others. But there are eleven principles of character education in order to be effective, namely: 1) promote the basic ethical values as the basis of character; 2) 
identify the character comprehensively to include thinking, feeling, and behavior; 3) use a sharp approach, proactive and effective way to build character; 4) create a caring school community; 5) provide an opportunity for students to demonstrate good behavior; 6) coverage of the curriculum meaningful, challenging, appreciate all students, are able to develop their character, and help them be successful; 7) the motivation of the students themselves; 8) the proper functioning of the entire school community as a moral community that shares responsibility for character development and faithful to the same basic values; 9) the division of moral leadership and broad support in building character education initiatives; 10) the proper functioning of families and community members as partners in an effort to build character; and 11) evaluate the character of the school as well as school staff function as teachers of the characters, as well as the manifestation of a positive character in the lives of students.

Character education and moral education that has a vision and a goal to develop and internalize moral values and character of the students should not be stuck on the indoctrinal inculcation approach. There are many option approaches and methods that can be used in teaching morals and character education to students. Even more important is the development of moral values/character system is integrated with the school, and do not make moral values/character as rote knowledge.

\section{CONCLUSION}

Development of morals or character of students through a number of subjects in formal educational institutions are becoming less effective due to the redundancy charge character/morality on some subjects as a separate subject. Character/morality has redundancy as the result of problem terminologies between moral education, value education, moral education, and character education. As a result of this terminological problem, character/morality presented in the curriculum subjects separately and keep it away from the moral problems of society. The low effectiveness of character education/character in formal educational institutions is due to evidently by the increasingly serious problem of the morality of the nation, including the younger generation, as well as a result of the educational character/character dominated by indoctrinal inculcation approach. Educational character/character that requires a process of habituation and exemplary is also not integrated into the school system. In fact, if the character education/moral system becomes an integral part of the school, the pattern of this integration will provide flexible options when it comes to contact with certain moral issues; can reduce the burden an already crowded curriculum; and avoid moral and character teachings as a mere cognitive knowledge. 


\section{BIBLIOGRAPHY}

Daud, Haji, Mustafa. (2005). Tamaddun Islam. Kuala Lumpur: Utusan Publications \& Distribution Sdn. Bhd.

Elias, John L. (1989). Moral Education: Secular and Religious. Florida: Robert E. Krieger Publishing Co., Inc.

Kohlberg, Lawrence. (1977). The Cognitive-Developmental Approach to Moral Education. In. D. Rogers (Ed.) Issues in Adolescent Psychology. New Jersey: Printice Hall, Inc.

Lickona, Thomas. (1992). Character Development in the Family. In Kevin

Ryan \& Thomas Lickona (Ed.), Character Development in Schools and

Beyond. Washington: The Council for Research in Value and Philosophy.

Lickona, Thomas, et al. (2007). Eleven Principles of Effective Character Education. Connecticut Avenue: Character Education Partnership.

Rest, John R. (1994). Komponen-komponen Utama Moralitas. In Kurtines, W. M. \& Gerwitz, J. L. (Ed.). Moralitas, Perilaku Moral, dan Perkembangan Moral. (Trans. M.I. Soelaeman \& M.D. Dahlan). Jakarta: Universitas Indonesia.

Rusnak, Timothy G. \& Thomas M. Farrelly \& Burrett, Kenneth, L. (1992) Integrated Character Education: Implementing a New Paradigm. In Ryan, Kevin \& Lickona, Thomas (Ed.) Character Development in Schools and Beyond. Washington: The Council for Research in Value and Philosophy.

Ryan, K., \& Bohlin, K. E. (1999). Building Character in Schools. San Francisco: Jossey-Bass.

Superka, Douglas P. (1976). Values Education Sourcebook: Conceptual Approaches, Materials Analyses, and an Annotated Bibliography. Michingan: Social Science Education Consortium.

Torney-Purta, Judith. et al. (2001). Citizenship and Education in Twenty-eight Countries: Civic Knowledge and Engagement at Age Fourteen. Retrieved from http://terpconnect.umd.edu/jtpurta/chapters/ch09.pdf.

Wessel, Ingrid. (1994). State Natinalism in Present Indonesia. In Ingrid Wessel (Ed.) Nationalism and Etnicity in Southeast Asia. Hamburg: Berliner Asien-Afrika-Studien.

Wynne, Edward A. (1982). Character Policy: An Emerging Issue. Lanham, MD: University Press of America.

Wynne, Edward A. (1988). Balancing Character Development and Academics in the Elementart School. Journal Phi Delta Kappan, 69(6). 